\title{
TRABALHADORES MÚSICOS MIGRANTES NA FORMAÇÃO DA MÚSICA AMAZONENSE CONTEMPORÂNEA
}

\author{
Migrant musician workers in the formation \\ of contemporary Amazonian music \\ Trabajadores músicos migrantes en la formación \\ de música amazónica contemporánea \\ Amós do Carmo Moreira ${ }^{1}$ \\ Bernardo Mesquita ${ }^{1}$ \\ Sara Aimée Ihuaraqui Nogueira ${ }^{1}$ \\ Mirian Chaves de Oliveira ${ }^{1}$ \\ Leonardo Corrêa e Silva ${ }^{1}$ \\ Taynara Coelho ${ }^{1}$
}

\section{Resumo:}

Este trabalho pretende apresentar a trajetória dos trabalhadores músicos migrantes dentro do processo de modernização capitalista da música no Amazonas durante os anos 70 e 80 . Refletimos sobre as transformações da música na região a partir do aspecto migratório da classe trabalhadora. Discute-se a importância das festas populares nos interiores e considera que a música passou pelo processo de autonomização. Fruto de reflexões sobre as entrevistas realizadas, apresentamos uma breve biografia de quatro músicos amazonenses, entre eles, Chico Cajú, Roberto Bope, Oseas Santos e Teixeira de Manaus.

Palavras-chave: Festas populares; musicologia marxista; trabalhadores músicos.

\begin{abstract}
:
This work intends to present the trajectory of migrant musician workers within the process of capitalist modernization of music in the state of Amazonas during the 70s and 80s. We reflect on the transformation of music in the region from the standpoint of the working-class migration. We will discuss the importance of popular festivities in the interior, and it will be highlighted how music passed through a process of autonomy. As a result of reflections on the interviews carried out, we present a brief biography of four musicians from the state of Amazonas which are Chico Cajú, Roberto Bopp, Oseas Santos and Teixeira de Manaus.
\end{abstract}

Keywords: Popular festivities; Marxist musicology; musician workers

${ }^{1}$ Universidade do Estado do Amazonas - UEA 


\section{Resumen}

Este trabajo pretende presentar la trayectoria de los músicos migrantes trabajadores dentro del proceso de modernización capitalista de la música en el Amazonas durante los años 70 y 80 . Reflexionamos sobre las transformaciones de la música en la región a partir del aspecto migratorio de la clase trabajadora. Se discute la importancia de las fiestas populares en los interiores y considera que la música ha pasado por el proceso de autonomización. Fruto de reflexiones sobre las entrevistas realizadas, presentamos una breve biografía de cuatro músicos amazonenses, entre ellos, Chico Cajú, Roberto Bope, Oseas Santos e Teixeira de Manaus.

Palabras clave: Fiestas populares; musicología marxista; músicos trabajadores.

\section{Musicologia Marxista e Imigração no Amazonas}

O desafio de compreensão acerca da formação da música amazônica contemporânea necessita de uma ferramenta teórico-metodológica capaz de captar a realidade em movimento fruto das múltiplas determinações pelas quais a região se caracterizou dentro da expansão capitalista na região a partir dos anos 50. Uma musicologia marxista sustentada pelo acúmulo da teoria marxista da dependência, TMD, assim como da contribuição antropológica de Darcy Ribeiro e Edgar de Assis Carvalho deve refletir sobre o ser humano concreto dentro de suas circunstâncias histórico-sociais.

Edgar explica que o marxismo antropológico foi inaugurado pela tese de Claude Meillassoux A Antropologia Econômica dos Gouro da Costa do Marfim em 1964, embora seja mais preciso considerar os estudos antropológicos realizados por Karl Marx no final da vida. É importante ressaltar que a antropologia marxista surge certamente a partir dos próprios escritos de Marx, e se desenvolve no que tange ao nosso interesse concreto por meio de autores tais como Darcy Ribeiro, o qual contribui decisivamente para o estudo do impacto do capitalismo sobre as sociedades indígenas no Brasil (ALMEIDA:2003).

Nos anos 70, o antropólogo Emanuel Terray afirma que as 3 instâncias do modo de produção estão na base da investigação sobre "as relações sociais concretas tais como se oferecem à observação do etnólogo são o produto de uma causalidade triplicemente complexa”. Estas relações sociais concretas são a síntese se múltiplas determinações, podendo até ser resultado da combinação de diferentes modos de produção (TERRAY: 1979: p.101).

Georgy Marcus afirma que a visão antropológica de Marx se encontra nos Manuscritos Econômicos Filosóficos de 1844. Marcus afirma que no pensamento marxista a concepção materialista-naturalista de homem apresenta o ser humano natural, vivo e ativo em sua relação metabólica com a natureza (MARCUS: 1974 p.8). Nos manuscritos, pela primeira vez, as categorias econômicas são a produção e reprodução da vida humana permitindo uma descrição ontológica de base materialista do ser social. Quando Marx deposita centralidade a produção e reprodução da vida humana surge uma base natural e social como uma dupla determinação tanto nos seres humanos como em seus objetos, relações e circunstâncias. Uma musicologia marxista deve recuperar a capacidade de compreender as práticas musicais desses homens na construção de sua história. (LUCKAS: 2018: p.562)

A produção musical dos músicos amazonenses durante os anos 70 e 80 deve considerar a condição migratória vivenciada por esses trabalhadores músicos. Esta condição é marcada pela transição de espaços sociais, pela transformação de referenciais culturais através do engajamento em novas relações sociais de produção musical capitalista. Um novo mercado musical regional é integrado no crescimento geral da indústria capitalista da música. Neste processo, observa-se uma autonomização das práticas musicais que adquirem um novo patamar qualitativo com a mercadorização musical criada pela indústria fonográfica.

É possível entender que a migração está profundamente relacionada a integração da economia regional ao mercado nacional capitalista. Cardoso e Miller apontam que "a evolução da população e do 
emprego enquanto redistribuição da massa de mão de obra requerida pela dinâmica regional, em um contexto de integração crescente à dinâmica do mercado nacional, se processa através de movimentos migratórios". (CARDOSO e MILLER: 1977 p. 62)

A ação do estado na promoção da expansão capitalista se estabeleceu coo expressão organizativa a partir da criação da SUDAM e BASA em 1966 e consolidou-se em 1974 com a criação do POLAMAZONIA. O desenvolvimento deveria se enquadrar ao modelo de "economia aberta" adotado pela ditadura em 1964.

O caráter primário da economia foi reformado e modernizado para atender os mercados internos e externos. Ianni explica que "a pretexto de efetivar a vocação do Brasil para produzir alimentos para outros países, o II PND definiu uma "estratégia agropecuária" voltada para o desenvolvimento extensivo e intensivo do capitalismo no campo" (IANNI: 1986 p.69). O trabalho de Ianni sobre o capitalismo na Amazônia ressalta a importância dos interesses econômicos de latifundiários e empresários rurais nos planos de desenvolvimento criados para a região.

O trabalho investigativo de grande fôlego feito por Mario Lacerda de Mello e Hélio A. Moura (1990) também é fundamental pois traça as origens dos migrantes em Manaus. No caso específico dos migrantes em Manaus, o levantamento de (MELLO e MOURA:1990) mostra que a maioria advinha de fora do estado e $44 \%$ dos migrantes advêm de áreas rurais do próprio Estado. As principais áreas de procedência do fluxo migratório oriundo dos interiores são os municípios de Itacoatiara, Manacapuru, Parintins, Careiro, na microrregião médio Amazonas, Tefé e Coari, na microrregião do Solimões-Japurá (MELLO e MOURA: 1990 p.347). Acerca das motivações dos trabalhadores para realizarem a migração o resultado do levantamento mostra que predominam as motivações econômicas ligadas ao trabalho e ao emprego. $\mathrm{O}$ desejo de um trabalho melhor, falta de trabalho e baixa remuneração são os principais motivos (MELO e MOURA: p. 351). Essas motivações correspondem a duas terças partes do total de motivações levantadas

A expressão o ganho era pouco foi muito ouvida durante os levantamentos. Mario de Mello afirma que "a precariedade das condições econômicas prevalecentes nos locais de residência anterior destaca-se, tanto entre chefes migrantes totais, como entre recentes, com peso quase absoluto na decisão tomada de mudaram-se desses locais" (MELLO e MOURA: 1990 p. 352). Mario deixa claro que as motivações econômicas, tanto dos amazonenses dos interiores quanto dos migrantes do resto do país, são predominantes. Ele afirma que "verifica-se que, tanto para um, como para outro desses dois contingentes, o desejo de um trabalho melhor afigura-se, no plano das razões econômicas, como a motivação dominante" (idem p.357).

\section{Festas populares no Brasil}

As festas estão sempre presentes na vida do ser humano, desde religiosas à profanas, e é nesse sentido que a história nos mostra o Brasil como uma nação multicultural que, foram formados pelos costumes e crenças de índios, negros e brancos.

A religiosidade predominante do Brasil enquanto colônia era o catolicismo, e os negros e índios, submissos aos seus senhores eram obrigados a participarem das cerimônias do costume europeu. O negro buscava forças em seus orixás, faziam seus rituais com cantos e danças, a alegria e o riso eram formas de socialização. Segundo Tinhorão, as festas possuíam um:

[...] caráter coletivo - tal como hoje o carnaval, por exemplo - eram inconcebíveis ao tempo da chegada ao Brasil de portugueses oriundo de uma Europa mal saída do controle teocrático da sociedade, através do conceito da responsabilidade pessoal ante o pecado, que impunha aos cristãos, vigilância permanente contra os impulsos pagão-dionisíacos herdados do mundo antigo. (TINHORÃO, 2000, p.7). 
A primeira missa foi a afirmação do poder real e espiritual sobre a terra achada, foi cortada a primeira árvore para a construção de uma cruz. Um ritual que os indígenas assistiram pela primeira vez e a tripulação das naus portuguesas que assistia à distância sem direito a participação. Um branco, chamado pelo nome de Diogo Dias entoou sua gaita e tamboril, tendo com ele os indígenas que dançaram e bailaram, marcando assim a primeira manifestação festiva realizada entre duas civilizações.

Nas Informações do Brasil, o Padre José de Anchieta faz uma crítica sobre os moradores das pequenas vilas portuguesas do Brasil de 1584, relatando que não seguiam moral pregada pelos religiosos, mas o seu convívio era em festas e cantorias, regadas a bebedeiras e comilanças, uma vida folgada e por certa depravada. Esse era o espírito dominante dos primeiros moradores: brancos de baixo poder econômico e são muito dados a festas. Esta expressão "são muito dados a festas" segundo o padre Fernão Cardim $^{2}$, refere-se aos habitantes da colônia que se misturavam portugueses, índios e africanos (TINHORÃO, 2000, p.40).

Tinhorão fornece uma explicação materialista para a predisposição pelas festas no período colonial, em que os brancos tinham quem trabalhasse em seu lugar, logo preenchiam o tempo ocioso com festas, tinham escravas negras e índias como suas mancebas, as mulheres e os filhos ornados de luxo excessivo com veludos e sedas. Uma simples comemoração era tratada como um grande evento e muita ostentação.

O povo estava sempre à margem das festividades oficiais ocupando a posição de espectador, mas eram nas solenidades religiosas e em algumas procissões que essa gente tinha oportunidade de se manifestar socialmente dentro e fora da igreja. Durante o período colonial, a mão de obra negra foi amplamente utilizada em outras atividades como na mineração e nas demais atividades agrícolas que ganharam espaço na economia entre os séculos XVI e XIX, e mesmo diante desses abusos, cantavam e dançavam, trazendo com eles seus costumes e cultos aos seus deuses, tendo permissão de seus senhores para fazê-lo. Realizavam seus rituais mesmo em forma dissimulada, suas danças (volteios), aos sons de tambores que os portugueses chamaram de batuques. (TINHORÃO, 2012, p.36)

A festa de negros documentada no Brasil oitocentos foi a festa do Rei Congo realizada pela irmandade Nossa Senhora do Rosário dos Pretos, em que na solenidade eram escolhidos um rei e uma rainha e seguiam em desfile pelas ruas, dando origem posteriormente ao maracatu pernambucano. As festas celebradas no Brasil colônia perduram nos dias atuais, como as festas juninas (São João, Santo Antônio, São Pedro), o rito da páscoa (Sexta-feira santa, sábado de Aleluia), Corpus Christi, Dia de Nossa Senhora de Aparecida (feriado nacional), Nossa Senhora da Conceição (feriado regional), o Natal e os Festejos do Divino, celebrado em várias regiões do país, e muitas outras festas do calendário católico.

Na herança africana, temos a Festa de São Benedito, Festa de Iemanjá. Na região amazônica, especificamente no estado do Amazonas, na cidade de Parintins, a festa popular dos bois Garantido e Caprichoso, retratam de forma teatro-musical a fusão da cultura indígena com o catolicismo, trazendo para arena a figura de Nossa Senhora do Carmo, Padroeira de Parintins e o xamanismo do pajé. Segundo Jamily Silva:

Percebe-se que as festas, nesse período, foram, também, um meio de diminuir as tensões inerentes à diversidade étnica e as distinções sociais da Colônia; entretanto, elas formavam e se consolidavam justamente a partir das diferenças culturais, da participação de múltiplos atores anônimos, do barulhento uso de ritmos e danças. Eram permitidos de participar dessas festas: índios, portugueses, negros, ciganos, espanhóis, franceses e quem mais pudesse ou quisesse. $\mathrm{O}$ intercâmbio entre as culturas aparece claramente nas festas da época, assim como suas mútuas percepções (SILVA, 2012, p.233). 
Eliberto Barroncas também nos faz uma descrição sobre a festa no beiradão:

Vamos fazer agora uma pintura de uma festa. Primeiro que essas festas, elas são anuais, e, muitas vezes, aquela comunidade, ela espera o ano inteiro pela aquela festa. Então a festa já acontece no esperar o ano, o próximo ano para novamente viver aquele momento. $\mathrm{E}$ numa realidade, que hoje eu sei que é bem diferente, mas, naquele momento lá, os namoros aconteciam na festa, e os namoros eram de ano em ano também. Por que era quando as comunidades iam. Você ia para as festas ali e tinham aqueles chamegos, e, quando o motor ia embora, parece que o amor ia embora junto também. Aquele motor que chegava com os músicos, eles vinham, os músicos de Manaus, por exemplo, né? Era muito comum para que a festa fosse boa... Chegou um momento em que se levava músicos de Manaus. Saxofonistas também, como o Rafi, Paulo Moisés, grandes saxofonistas, músicos da banda da polícia. Então eles chegavam tocando, normalmente eles chegavam assim pela parte da tarde ... umas três horas. Essas festas, a organização, tem o torneio de futebol ... daqui a pouco vinha o motor todo enfeitado de bandeiras tocando [cantarola a música Vassourinha] chegava tocando frevo, sempre uma música animada, uma marcha, e as pessoas da festa, da comunidade soltavam foguetes, esperando essa música. Então era um momento em que até parava todo mundo pra compartilhar, pra viver de fato, né? Vivenciar aquele momento de chegada. Então, depois do futebol, todo mundo ia pra casa, ia tomar um banho e voltava cheiroso, né? O perfume, eu me lembro que era um perfume chamava Tabu... é o meu perfume predileto até hoje! Que era um perfume que era vendido pelo regatão, levava o Tabu pra vender. O meu tio, esse meu tio que tocava Sax, era regatão também. Por que, nas danças, as mulheres tinham cheiro de Tabu, então isso fica na memória, e acontecia a festa com essa riqueza de valores, as músicas do rádio, e elas eram vivenciadas naquele momento da festa, e aquela sociedade vivia, nesse aspecto, em função das festas. Isso era a coisa mais importante (informação verbal). (ELIBERTO apud LIMA:2020 p.42)

\section{A Música de Beiradão: Um fenômeno Amazônico}

A Amazônia em suas peculiaridades culturais e históricas é única no ponto de vista das tradições e costumes deste lugar. A expressão Música de Beiradão foi criada pelos radialistas e produtores musicais inseridos na indústria musical capitalista a partir da década de 60 e 70 . Sinaliza a separação da música em relação às festas antes duas instâncias coesas e integradas. Neste processo de modernização capitalista fora permitida que a música fosse tratada como uma esfera autônoma devido a ampliação e expansão do mercantilismo musical tanto no mercado musical dos interiores como pela influência expansionista do mercado musical nacional e internacional com a instalação de gravadoras e selos fonográficos na região norte, especialmente a gravadora Gravassom localizada em Belém.

A música Amazônica existia, sobretudo nos rituais dos povos nativos indígenas, quando nos momentos de oferendas e no início e término de ciclos (de plantio e de colheita), mas tarde com a absorção impositiva da cultura, principalmente a religiosa de portugueses e espanhóis, formando deste modo um calendário de eventos (festas) em homenagem aos santos da igreja católica, religião oficial desde a época da colônia.

Observando uma comunidade no baixo-amazonas no ano de 1948, Galvão diz:

O catolicismo é francamente dominante. Não é, porém, uma concepção integral da vida, visando a uma transcendência. É um culto quase fetichista em torno de santos, não de santos considerados como membros de uma igreja triunfante, e sim de determinadas imagens às quais se atribuem poderes mágicos. O pároco está longe. A “desobriga” ocorre uma ou duas vezes por ano. De modo que as atividades religiosas são desempenhadas em irmandades (GALVÃO: 1976) 
Como na época do descobrimento e das capitanias, as principais rotas de transporte eram marítimas, pelo litoral brasileiro, sendo a ocupação se alastrando do litoral para o interior do continente, assim, no norte do brasil, as principais formas de transporte são fluviais, alcançando os mais remotos e longínquos rincões da Amazônia, pelos rios onde a subida e descida das águas tornam as estações da seca e da chuva uma questão de sobrevivência , influenciando também no ciclo das festas, daí a referência a música de Beiradão, essas comunidades ribeirinhas que se instalam a beira das barrancas caídas dos rios , nos palafitas da várzea, por todo o curso dos rios das calhas e bacias da região norte.

Mais resistente como forma de mobilização organizada de massas humanas em eventos de rua, ao conciliar o caráter (em princípio solene) de seus desfiles processionais com a disposição para o lúdico das maiorias, apenas as solenidades tradicionais do calendário da Igreja Católica continuariam a manter vivo o equilíbrio de interesses entre o poder (no caso espiritual) e o simples desejo de diversão popular (TINHORÃO: 2000: p.133).

A devoção e as tradições aprendidas ao longo do tempo, conjuntamente com a necessidade humana de socialização, numa região com uma densidade demográfica baixa, mas que no passado foi ainda pior no período em que apenas missionários, indígenas, e pouco extrativista e pescadores habitavam a Amazônia. Essa característica local, que causava enorme movimentação nas comunidades e mobilizava todos os segmentos da sociedade em prol dos festejos dos Santos, grandes eram os festejos por toda a Amazônia, alguns se mantém até os dias de hoje, com o mesmo propósito e devoção, como exemplo podemos citar as Festas de Santo Antônio (de Borba), Nossa Senhora do Carmo (Parintins), Nossa Senhora da Conceição (Manaus).

De grande importância para o entendimento das práticas musicais nas beiradas de rio no Amazonas são as sedes, locais onde eram realizados os bailes, geralmente construídas de madeira com longas canelas tipo de palafita com assoalho sem repartições internas com pequena varanda onde se realizavam as danças e folgas do povo depois das procissões e missas em homenagens aos santos.

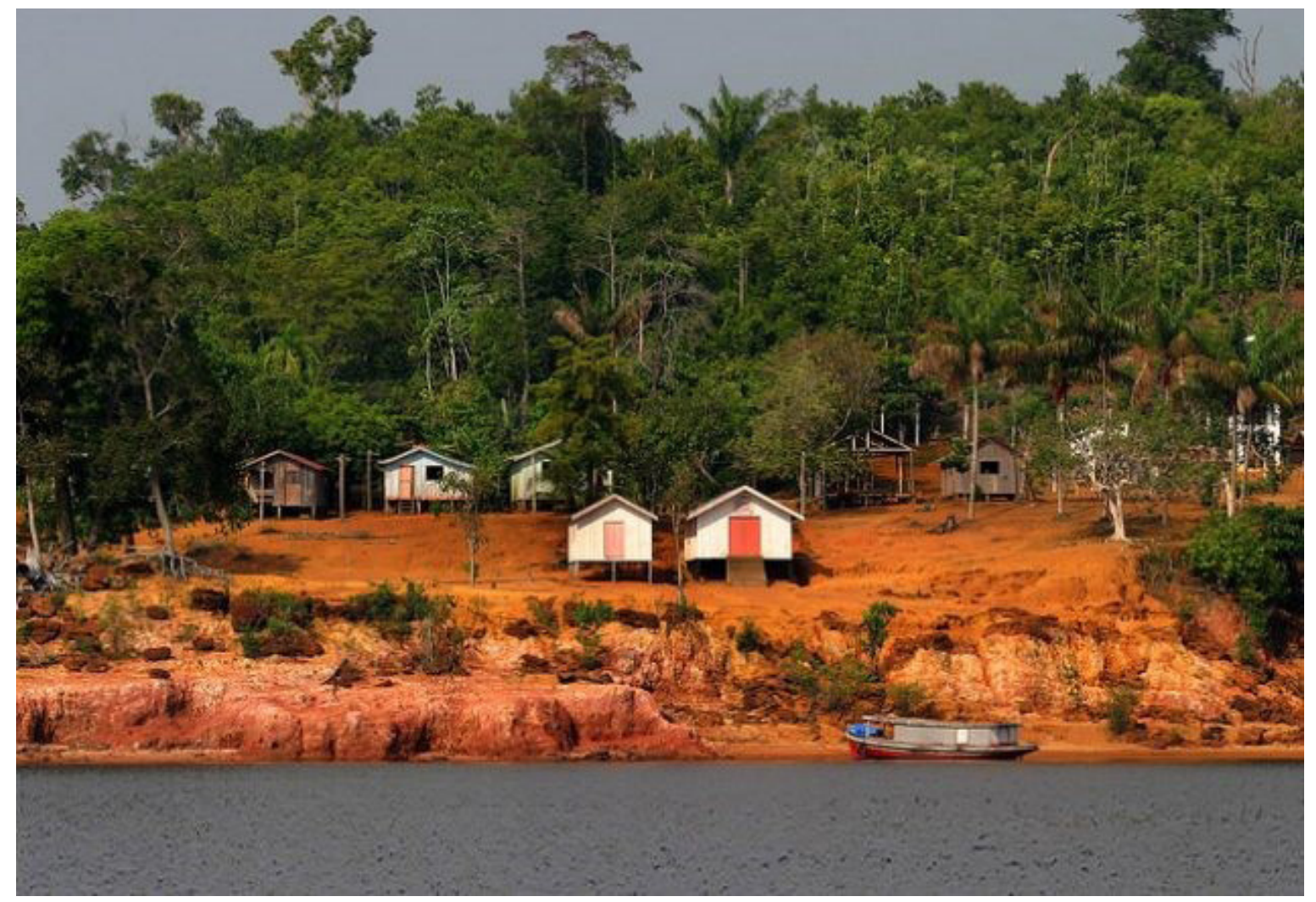


Como todas as atividades em torno das festividades de cunho religioso, havia a necessidade de música, isto é, de músicos que fizessem o acompanhamento dos hinos, canções, ladainhas e demais cantos (litúrgicos ou não) que animassem os festejos, foi então que músicos de diferentes formações e repertórios começaram a integrar as comunidades ribeirinhas no período dos festejos (de 13 de junho a 27 de dezembro). Havia o tempo de festas e o tempo de não festas, juntos trabalhavam para o esplendor deste acontecimento, pois havia também uma concorrência velada em torno de quem organizava a melhor festa em determinada localidade.

As festas, ladainhas e novenas são importantes práticas chamadas de respeito. Essas práticas consistem nas relações estabelecidas pela comunidade com os santos a fim de cumprimento das promessas. A música dentro das festas de santos, portanto, certamente tem um caráter funcional-religioso, o que pouco a pouco foi sendo transfigurado na expansão capitalista em curso a partir dos anos 50 .

Ao longo do tempo foram incorporadas pelas irmandades outros tipos de costumes e tradições locais, ora que, muitas vezes se misturavam a contos folclóricos e antigas estórias e lendas amazônicas, além dos costumes trazidos pelos portugueses nos festejos de São João, São Pedro e Santo Antônio, as quermesses, os jogos, as comidas típicas e as danças (quadrilha, arrasta-pé).

Com a migração de nordestinos para a Amazônia durante a grande seca dos anos 20, e as inovações tecnológicas do início do século (a eletricidade, o rádio, o gramofone etc..), colaboraram para que as festas dos santos tivessem agregado aos cantos da igreja católica, músicas regionais e lamentos de retirantes da seca que tiveram identificação pelas tradições do baião, xaxado, xote, além dos ritmos dos batuques negros e as modinhas.

A música executada nas festas (dos santos) foi se modificando à medida que o povo do interior do Amazonas, começou a ter contato com outros estilos musicais por meio do rádio, discos, difusoras (boca de ferro) e também pela absorção da cultura nordestina vinda com os migrantes, o forró (como gênero musical) foi muito apreciado pelos ribeirinhos, visto que, com uma formação instrumental reduzida (sanfona, zabumba e triângulo) podia entreter o público com música por uma noite inteira, e também por não haver necessidade imediata de amplificação, sendo usados de forma acústica, demandando intenso esforço dos executantes, outras formações também foram bastante utilizadas como o regional (cavaquinho, violão, atabaque, pandeiro e um instrumento solista saxofone, flauta ou clarinete) que alegrava os arraias das comunidades, na linguagem dos músicos tocavam no seco, isto é, sem aparelhagem de sonorização.

Essas formações instrumentais eram comuns até meado dos anos 70, quando um movimento impulsionado pela energia elétrica (motores de luz/geradores) e caixas de som com amplificação e a inserção de instrumentos mais modernos (guitarra e órgão) tiveram uma nova onda musical, lembrando que a música considerada de Beiradão consiste num repertório não formal nem estereotipado, de forma democrática havia o samba (Chico da Silva, Cartola), o forró (Luiz Gonzaga), o brega (Osvaldo Braga), e a partir dos anos 80 ainda agregou a esse caldo estilos muito presentes na música paraense como o Carimbó, Lambada, Cadence-Lypso e Merengue. Hoje a guitarrada representada pelo mestre Mario Gonçalves, Aldo Sena e Joaquim Vieira inspiraram grandes músicos amazonenses como o também mestre Oséias e sua guitarra maravilhosa.

Chico Caju e Teixeira de Manaus, e outros artistas que de forma simples iniciaram suas carreiras, ou despertaram pra elas através dessa transição da música litúrgica das festas de santo, para um viés popular de música regional que a partir de então dominou o som do interior do Amazonas. Embora tenham nascido no interior e mantido atuação constante nos festejos, a música destes músicos já estava integrada e em sintonia com as tendências dominantes na industrial musical capitalista desde os anos 60.

Os locais dos eventos também mudaram, dos pátios das igrejas e praças, para locais não tão cristãos, associações de moradores, bares flutuantes e até prostíbulos. As famosas Sedes no médio Amazonas, eram locais onde durante o dia (festejo) havia disputas esportivas e almoços comunitários, e a noite a festa ficava por conta das atrações conjuntos musicais ou aparelhagens de som vindas da capital. As Sedes mais 
conhecidas, onde haviam verdadeiras procissões fluviais em dias de festas, eram a do Flamengo no furo do Paracuúba (nas proximidades de Manaus), a do Grêmio em Autazes-açu, e Ferroviário em Tefé.

As festas de Beiradão, o som ribeirinho e a simplicidade do homem do campo representado no caboclo quebrando o silêncio da selva, está imortalizado o forró, o brega a lambada e o que mais tocar na alma e mexer com a emoção dos que esperam um ano inteiro para se divertir e esquecer um pouco os problemas de quem vive as margens do rio, tendo que a cada dia buscar uma forma de sobreviver, e ter pequenos momentos de alegria patrocinados pela fé e pela tradição.

Segundo a etnografia de Eduardo Galvão realizada em 1948 podemos constatar a existência da prática musical secularizada em forma de divertimento onde "as danças são realizadas em casas particulares ou clubes, onde a admissão é paga. Os indivíduos que organizam esses 'divertimentos' não têm relação alguma com a igreja ou com as irmandades, seu motivo é o lucro comercial" (GALVÃO, 1976 p.61).

As transformações ocorridas nas práticas musicais no sentido de uma autonomização não acontecem apenas a partir dos anos 80 com a chegada dos músicos na indústria fonográfica, já que podemos observar certa autonomia dentro dos próprios festejos realizados nos interiores.

\section{A trajetória musical de Chico Cajú}

Segundo Norberto "Francisco Ferreira do Nascimento, mais conhecido pelo apelido e nome artístico Chico Cajú, nasceu no dia 03.10.1943 em uma localidade rural na beira do Lago do Ajará, pertencente ao município de Manaquiri que tem uma distância cerca de $80 \mathrm{~km}$ de Manaus" (NOBERTO: 2016 p. 54). Um de seus ofícios no interior foi o trabalho com a Juta, com a Malva, com roça. Vindo de uma família de músicos foi no seio de sua família que teve seu primeiro contato com a música até que decididamente veio morar em Manaus, para então se dedicar diretamente esta atividade.

Seu pai tocava violino, o irmão tocava banjo, o outro irmão pandeiro, e o outro a bateria. Com eles teve até uma bandinha familiar durante um tempo. Iniciou sua trajetória musical aos 12 ou 13 anos, com os instrumentos percussivos como o pandeiro, bateria e até banjo e logo depois iniciou os estudos para tocar saxofone. A trajetória do saxofonista Chico Cajú, foi construída nas festas realizadas nas sedes e beiradas das comunidades dos interiores. Os festejos aconteciam em diferentes municípios tais como Porto Velho, Tabatinga, Manicoré, Tefé, Alvarães, e em várias outras localidades do Amazonas. (NOBERTO: 2016 p. 55).

Segundo o próprio Chico, os festejos duravam a noite inteira até o início do outro dia. E eram sempre cheios de energia e alegria. Algo de importante inspiração para ser lembrado na vida desse grande artista Amazonense.

O período formativo de Cajú deu-se a partir da formação instrumental da Lacapaca composta por sax, trombone, pandeiro, banjo. Esses instrumentos também são relatados por Eduardo Galvão que menciona "um grupo de músicos que acompanha a folia utilizando sopro, flauta, cordas, violão e cavaquinho" (GALVÃO, 1976 p. 40).

Segundo o relato de inúmeros músicos amazonenses, essa formação instrumental predominante até os anos 70 quando os instrumentos elétricos começaram a substituir os acústicos e os festejos nos beiradões, que começaram a ser animados com aparelhagem sonora.

Aos 19 anos se casou e teve cinco filhos de seu primeiro casamento. E com os seus 20 anos ga- nhou de seu pai um saxofone alto, o que incentivou ainda mais o seu interesse pela música, pois foi com o saxofone alto que ele era convidado para os festejos que o fizeram ser conhecido no Amazonas. Sua técnica usada para aprender a tocar é também conhecida como o tirar de ouvido e muitas de seus repertórios eram músicas de vários artistas, Pantoja do Pará, Manezinho, o Paulinho, Elson Brenha. (NOBERTO: 2016.idem).

A trajetória de migração de Chico Cajú faz parte de uma geração marcada pelo fluxo das populações dos interiores a Manaus. As motivações para a migração tinham a ver com a necessidade de aperfei- 
çoar sua técnica instrumental, divulgar seu trabalho e obter reconhecimento como músico profissional. Ou seja, ser reconhecido como um profissional que vive e recebe financeiramente para tocar

Aos 28 anos passou a morar em uma comunidade na Costa do Tanaboca, no Solimões. Aos 30 anos, decidiu então ir com a família viver na capital Manaus. Sobre a chegada do Sax no interior, Chico diz que não se tinha muito acesso a instrumentos como o saxofone, porém as bandas de Manaus tocavam no interior e o que fizeram com que despertasse o interesse de Chico pelo instrumento, e de vários outros músicos de sua geração. É importante ressaltar que quando Cajú começou a tocar nos anos 50, 2 saxofonistas amazonenses se destacavam nas festas do interior: Paulo Moisés e Rafí.

Músicos da banda da polícia militar, atuavam fortemente demonstrando como havia uma um fluxo de músicos entre capital e interior durante as décadas de 40 e 50.

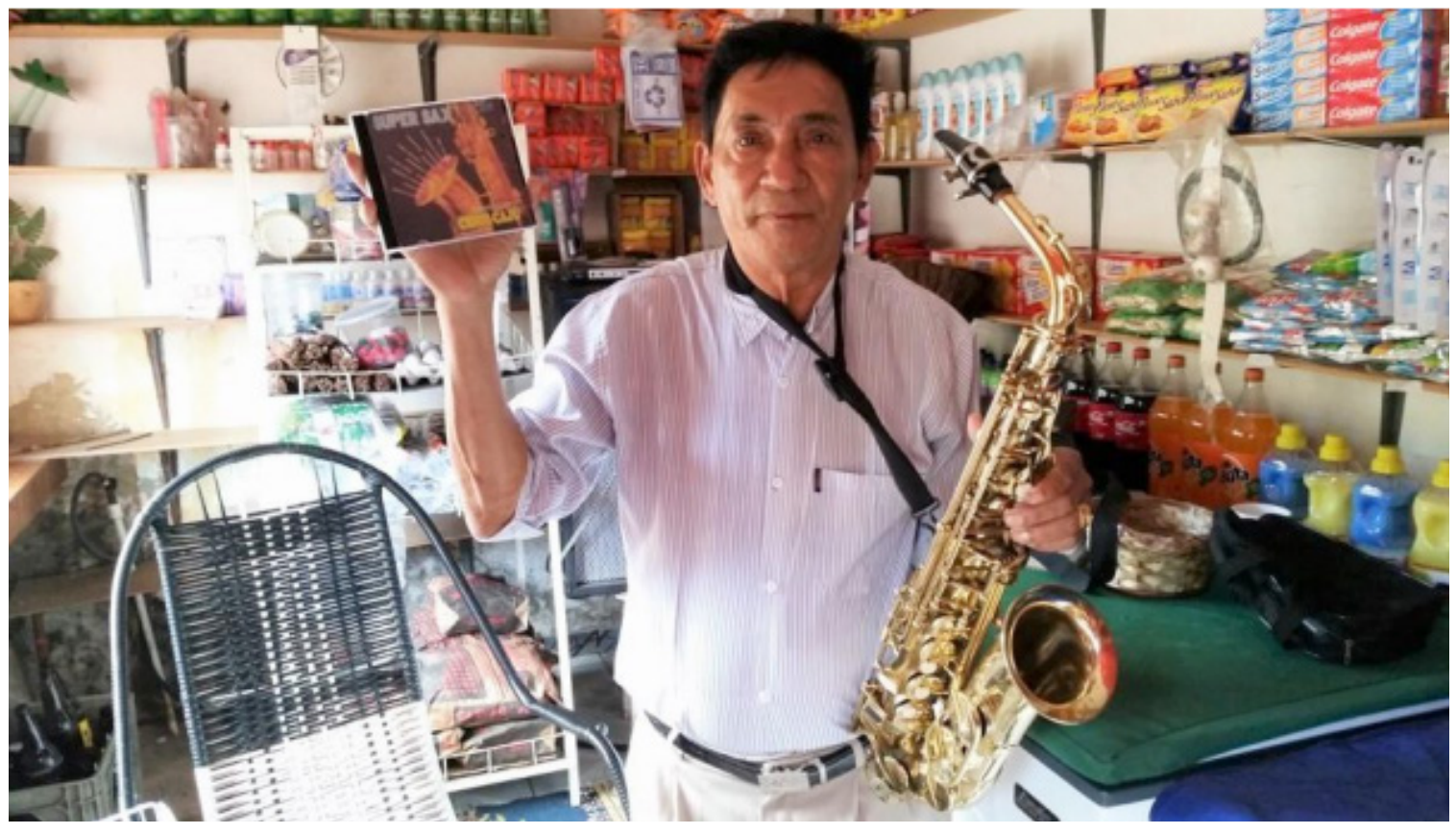

Chico Cajú em sua mercearia São Francisco. Fonte: (NORBERTO:2016 p.53)

Sua carreira discográfica começou quando, em uma de suas apresentações nos festejos de São Pedro em Manaquiri, foi apresentado para Zé Milton, que o instigou a gravar uma fita com 5 de suas músicas autorais para levar a um amigo que se encontrava em Fortaleza, Carlos Santos. A fita foi aprovada e Chico viajou para Belém, esquecendo, porém, o seu Sax, o que causou bastante tensão até que Pinduca conseguisse arranjar um sax pirento de improviso. Mesmo com um Sax visivelmente inutilizado, Cajú o limpou e ajustou para que conseguisse fazer as suas gravações. Esta história acompanha o processo de gravação do primeiro e melhor disco do artista, segundo o próprio artista. O disco também foi um sucesso de vendas atingindo 200.000 Cópias. O segundo disco chegou a marca de $186 \mathrm{mil}^{2}$.

Em Manaus durante os anos 70, Cajú participou da Banda Pop, também conhecido como grupo pop, com a formação instrumental de baterista, guitarrista, contrabaixista, o vocal, tecladista e saxofonista. Apesar de ser um grupo de Manaus, a maior parte de suas apresentações aconteciam nos interiores e seus

\footnotetext{
${ }^{2}$ Cajú gravou três LPs no estúdio Gravasom em Belém (PA) e três CDs posteriormente em Manaus (AM), sendo que o último (A Volta do Sax, 2013) está fazendo sucesso em todo o interior do Amazonas. Os LPs gravados foram: Super Sax (1983), Chico Cajú e seu Super Sax (1985) e fungando no Cangote Dela (1990). Ambos tiveram ótima aceitação e repercussão no Estados do Amazonas (NORBERTO: 2016).
} 
repertórios eram variados desde o bolero, forró, xote, valsa. Chico comenta que na década de 1980 as bandas requisitadas em clubes como o Clube no Rio Negro, eram as bandas de Bailes.

Observa-se como a desigualdade social se expressa na realidade diferenciada destes grupos de trabalhadores músicos. Enquanto havia aqueles trabalhadores mais pobres que tocavam em festas dos beiradões, os músicos de classe média eram bastante requisitados para animar em bailes de elite.

\section{A trajetória musical de Teixeira de Manaus}

Teixeira de Manaus. Nome artístico de Rudeimar Soares Teixeira, nasceu em 08 de dezembro de 1944, na Costa do Catalão, comunidade ribeirinha pertencente ao município de Iranduba. Pertencente a uma família de 12 irmãos, seu pai conhecido como Seu Teixeira, Raimundo Azevedo Teixeira e sua mãe Dona Doca, Theodózia Soares Teixeira, eram agricultores. Teixeira de Manaus era um dos filhos mais novos e foi enviado à Manaus para estudar em 1953 aos seus 9 anos de idade, em um Colégio Progresso de Júlia Barjona de Labre. (TEIXEIRA: 2018 p. 83)

Segundo a pesquisadora Darle Teixeira, o Teixeira de Manaus, por diversas vezes expressou-se desgostoso em ter que morar longe de sua família que estava no interior e ter que ir para a cidade para estudar. Em seus relatos, desde cedo teve que trabalhar para ajudar pagar seus estudos, então desde engraxar sapatos à auxiliar nos deveres do patrimônio da escola ele auxiliou.

Foi um aluno esforçado e comprometido com seus estudos, e segundo a uma entrevista dada ao jornal A Crítica, em 1993, atribuiu o desejo pela música porque seu pai tocava pistom da banda do colégio o que o influenciou a ter interesse pela música e pelo Saxofone, instrumento que aprendeu sozinho. Em 1966, quando ainda morava em casa de amigos do pai, começou a animar festinhas de aniversários de amigos com o sax e a tocar nos carnavais de rua da cidade de Manaus. Na década de 70 criou seu próprio grupo musical com o nome de RT4, Rudeimar Teixeira e 4 (quatro) componentes. Passou de músico-integrante a músico-empresário. 1975 fora a data que o pesquisado relatou ter sido batizado carinhosamente de Maestro Teixeira e ficou fixo nas boates noturnas de Manaus e no Parquinho 2.000.

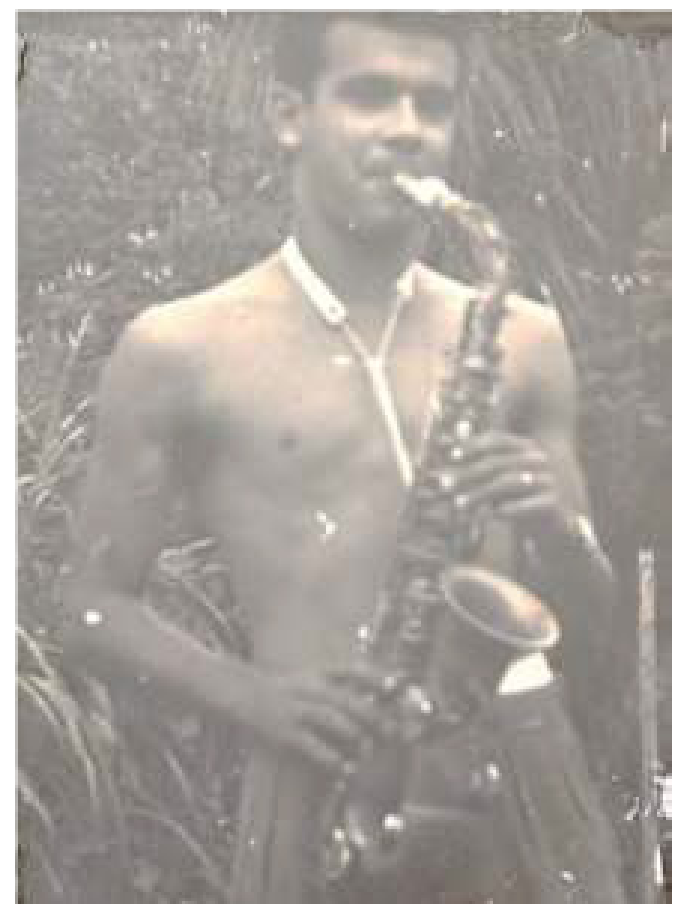

Primeiro sax (16 anos) - terreiro da casa dos pais na Costa do Catalão. Fonte: Acervo pessoal 
A sua relação com o Seu Lourival o dono do Parquinho 2.000 onde trabalhava foi de grande parceria e amizade o qual o mesmo foi padrinho da filha mais nova de Teixeira em uns de seus relatos sobre o tempo que esteve à frente dos grupos o qual era responsável em gerenciar. Segundo Darle Teixeira, longe de qualquer lazer se tratava de um trabalho árduo. Era preciso encarar a arte como profissão e quem trabalhava com ele era preciso estar nos dois momentos de apresentação: o que antecede (ensaios) e que devem ser entendidos como produção remunerada e o da apresentação em si. Teixeira de Manaus, além do Parquinho 2.000, ainda tocava noutros lugares. Saramandaia, um dos rendez-vous dos anos 70 e que fora o palco literal do convite para entrar na indústria fonográfica. Sobre esse momento significativo, Teixeira diz:

Eu tava lá no cercadinho. Ele foi com um empresário que levou ele "vamos ao Saramandaia”. Quem vinha pra cá, após seu evento lá na cidade... chique, ia nos ver tocar. Nosso conjunto era muito bom e ia nos ver tocar. O Pinduca foi uma vez, foi outra e ia lá comigo e é aquela história. Insistiu, insistiu pra eu fazer uma fita e coisa e eu pensei que era brincadeira e tal... agora, resumindo: até que um dia eu fiz essa fita e ele foi lá e levou a fita. Até que um certo dia o telefone tocou e era pra eu ir. Aí, automaticamente... foi uma coisa tão bem-feita que o Saramandaia, que eu queria deixar o conjunto tocando lá, mas tava caindo né, Darcy? Foi caindo, caindo, caindo, e eu fui entrando na vida de disco, e o Saramandaia foi fechando. Não sei o que foi isso. (TEIXEIRA, 2017: p.90)

Neste trecho de sua entrevista, Teixeira de Manaus fala que foi uma coisa tão bem-feita, pelo fato do sucesso de sua gravação não depender de uma gravadora de disco que estava em processo de falência, e por simplesmente conseguir que seu trabalho fosse prestigiado de tal forma. Assim, podemos dizer que Teixeira de Manaus é considerado um dos precursores do estilo de música instrumental da Amazônia registrado nos discos a partir dos anos 80 .

\section{Roberto Bopp}

Roberto Bezerra nasceu em 1955 na ilha das cobras localizada aos arredores de Parintins no interior do Amazonas. Antes de fazer história na música, ele trabalhou com atividades manuais com seu pai, na extração de juta. Seu primeiro contato com a música foi na infância, em festas proporcionadas por fazendeiros de juta, com instrumentos sem captação elétrica. Mas somente aos 19 anos iniciou sua carreira musical.

O desenvolvimento do capitalismo trouxe muitas mudanças paras as famílias pobres que viviam do extrativismo e das lavouras, tanto da borracha como da juta, onde muitas vezes não havia as relações com dinheiro. Na tentativa de mudar a realidade da família, Roberto decide ir para a capital em 1964 onde começou a estudar violão aos 19 anos, com um segurança do Distrito Industrial, onde trabalhou por pouco tempo. Ele aproveitava todos os intervalos para treinar, e mais tarde monta seu primeiro grupo de samba juntamente com seu professor, Raimundo Dutra, denominado Canoeiro. O grupo se mostrou bem adaptado a tocar em todos os tipos de eventos, de casamentos a prostíbulos.

No entanto, não teve apoio familiar e foi aconselhado a tentar outras oportunidades de carreira, como jogador de futebol. Participou da Escola do América Futebol Clube e foi treinado por Amadeu Teixeira. Mas era claro que sua paixão e vocação se deu na área musical, mesmo se aventurando em várias áreas de atuação, teve importante influência na música e história do Amazonas.

Por meio da criação da banda Carrapicho, em 1978, Roberto fez parte de uma geração criativa e impulsionada pelas mudanças socioeconômicas na região. A banda Carrapicho foi criada com interesses competitivos. Roberto trabalhava no SESC e foi solicitado a ele que fundasse uma banda para concorrer com a banda do SESI. A ideia deveria ter sido extinta, mas a vontade de Bopp era de fundar uma banda,

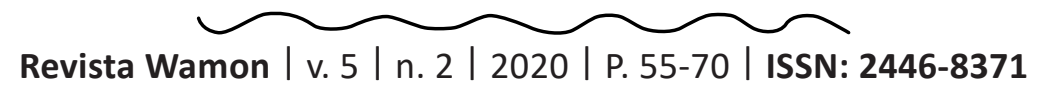




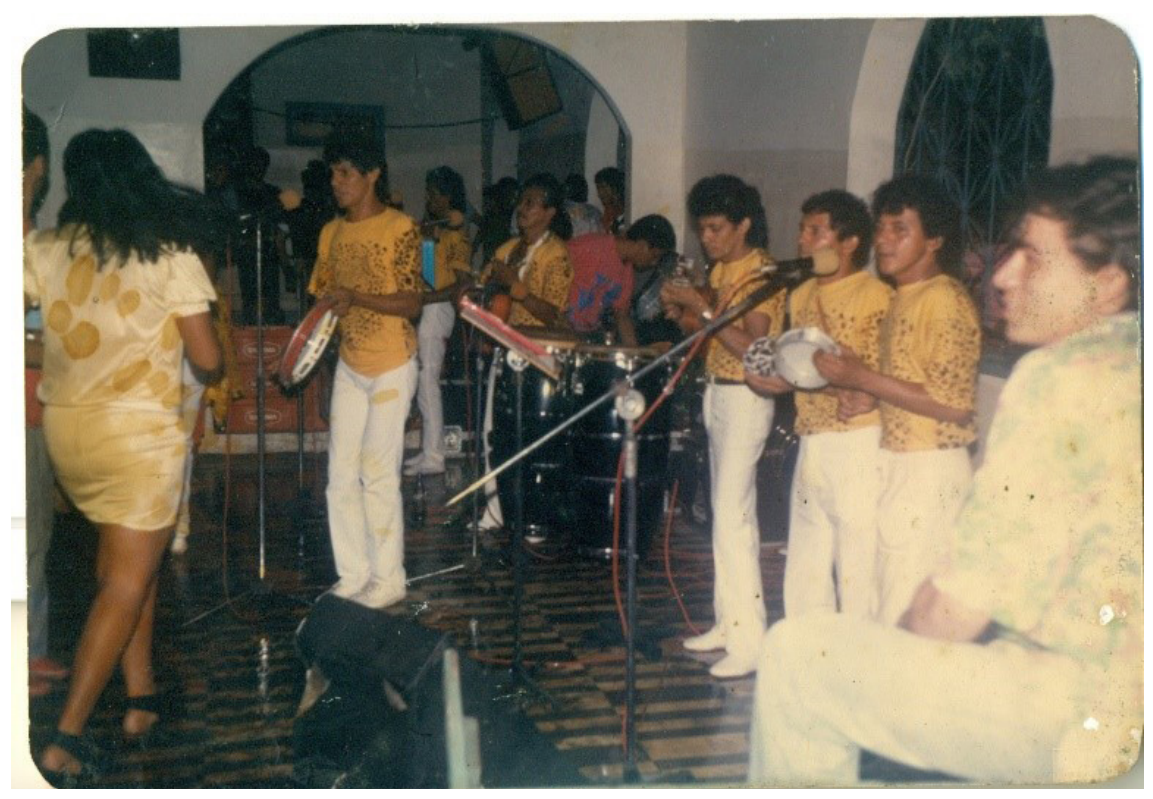

Bopp e o Grupo Canoeiro em 1980. Fonte: Acervo Pessoal.

e assim ele persistiu até o surgimento do grupo Carrapicho. Com o passar do tempo, a banda adquiriu sucesso, se tornando um fenômeno amazonense, e passando a se apresentar em vários lugares de Manaus.

A inspiração do nome se deu pelo contexto da palavra carrapicho, originário de uma planta que não desgruda com facilidade, trazendo uma ideia de frear o avanço da música estrangeira por grudar no gosto popular. Esse nome foi sugerido por um amigo dos integrantes da banda chamado Nil Cruz, que auxiliou na influência da banda por meio do nome, com o intuito de conter o avanço da música estadunidense, que predominava na época, influenciada pelo contexto externo muito visado na época da ditatura militar.

Essa oposição refletia-se na permanência da instrumentação tradicional do forró, indo contra as tendências instrumentais da época para bandas que se utilizavam de teclado guitarra e baixo enquanto eles se utilizavam de sanfona, percussão e violão. Somente no primeiro LP de 1985 é possível perceber a presença do baixo, guitarra e bateria em suas músicas.

A história, força e influência de Roberto Bopp e o grupo Carrapicho foram importantes para a cultura regional amazonense. Por meio da banda Carrapicho houve uma marca do regionalismo cultural na história.

\section{Ozeas da Guitarra}

Ozeas Silva dos Santos nasceu na comunidade do São Raimundo, pertencente ao município de Maraã, interior do Amazonas no ano de 1958. A influência musical veio de casa com seu pai que lhe apresentou a música através do violino, banjo e violão, instrumentos que fazem parte da cultura amazonense. Aos 10 anos, na cidade de Tefé, ele ingressou num conjunto chamado Uirapuru tocando guitarra elétrica emprestada. Esta foi uma oportunidade para ele mostrar seus talentos em solos, e já na adolescência foi contratado para tocar em vários locais da cidade. O repertório do grupo era baseado em Brega (cafona), forró, boleros, canções românticas e lambada.

Morando em Coari, uma cidade próxima, Ozeas continuou tocando com bandas que faziam o mesmo estilo de suas primeiras experiências, consagrando sua influência na guitarra elétrica. Juntamente com Joaquim Vieira e Mario Gonçalves, do Pará, Ozeas Santos faz parte da história como um dos primeiros nomes da guitarra na Amazônia. Com a música sonorizaram uma história de transformação social de 




Ozeas dos Santos em 2020. Fonte: Acervo Pessoal

grande proporção, marcada pela mudança de um país rural para urbano e moderno, no qual a presença da guitarra elétrica é um símbolo representativo. A partir daí surgem os nomes de Ozeas, Vieira e Mauro Gonçalves entre outros nomes, que iriam contribuir para a construção de um novo estilo dentro dos moldes da indústria musical. Surge então a Lambada.

A influência, incentivo e apoio do pai foram fundamentais para consolidar a música e carreira do jovem Ozeas. Em 1976, aos 18 anos, ele resolve se mudar para a capital do Amazonas, Manaus. Num momento de muitas mudanças sociais acontecendo, além do crescimento da indústria fonográfica, a situação para os músicos não estava fácil, principalmente os pobres vindos do interior.

Ozeas fez apresentações em diversos locais de Manaus e interiores, além de muitas parcerias com outros grupos locais como o grupo Play Pop. Com ajuda de conhecidos chega a Belém, onde fez seu primeiro registro fonográfico, com o grupo Lambaly, em 1980, pela Gravassom. O sucesso foi aumentando ao ponto de começarem a participar de programas da TV local.

O sucesso desse primeiro compacto o levou em 1983 a lançar o seu primeiro álbum solo gravado em São Paulo pela gravadora Copacabana, que lançou mais 4 discos de Ozeas. Essa gravadora viu muito potencial econômico nas estrelas desconhecidas do Norte e Nordeste, especialmente nos seguimentos musicais queridos dos trabalhadores mais pobres no Brasil, tais como Sertanejo, Lambada e Forró. Por isso, do Amazonas contratou Ozeas e Teixeira de Manaus, entre outros. Os Anos 80 vieram para alavancar a sua carreira solo e consolidar seu nome na cultura musical como guitarrista.

A vida em São Paulo foi um marco na sua carreira que só crescia até seu trágico acidente. Em Manaus, um acidente de carro o fez parar com as gravações por 2 anos. O músico teve passagem também por Fortaleza onde morou por 1 ano, consagrando seu nome também no nordeste do Brasil.

O sucesso de Ozeas se deu pelo seu estilo único com a guitarra, sempre impressionando o público com solos diferenciados e cheios de personalidade. Seu estilo característico não tinha influencias de outros músicos, pois ele afirma que só tinha tempo para sua própria música, sendo seu pai sua única influencia.

Os anos 80 marcaram o início da produção discográfica no Amazonas e esse crescimento do capitalismo trouxe para a cultura da região norte, especialmente no Amazonas, transformações no que diz respeito a instrumentação musical, com muitos músicos iniciados nos instrumentos acústicos de corda, como percussão, violão, 
cavaquinho, saxofone, violino e banjo, trazendo agora as obras e influência dos guitarristas com sua arte elétrica. A música de Ozeas trouxe visibilidade ao Amazonas e certamente faz parte das raízes culturais da música brasileira.

Ozeas passou por várias cidades do norte e nordeste do Brasil. Em Belém, Coari, Fortaleza, Tefé, Manacapuru, Manaus. Dentre suas músicas mais famosas que fazem referência às cidades por onde andou estão Cidade de Tefé, Alô Fortaleza, Lambada Amazonense.

\section{Considerações finais}

Nos últimos anos o surgimento de pesquisas inéditas sobre a música do Amazonas 3 permitiram ampliar e aprofundar as reflexões sobre o fenômeno contemporâneo da música nortista. A promoção do capitalismo a partir do dirigismo autoritária da ditadura acentuou a condição de dependência na Amazônia ao capitalismo monopolista transnacional pois a região acabou sendo instrumentalizada para a acumulação de capital no Centro-Sul e nos países do capitalismo central. A inserção dos trabalhadores músicos no mercado capitalista reflete essas determinações gerais.

Levando-se em conta o que foi observado sobre a trajetória dos trabalhadores músicos durante a modernização capitalista, a musicologia marxista busca compreender as práticas musicais dentro do desenvolvimento histórico. Nos anos 70 e 80 os músicos amazonenses estão em migração em direção as cidades e capitais em busca de melhores condições de trabalho. As motivações econômicas são predominantes entre os migrantes.

Pode-se destacar que o Brasil é uma nação multicultural dentre os diferentes costumes e crenças dos índios, negros, e branco, as festas estão presentes tanto no meio religioso quanto no profano. No Período colonial, os negros e os índios eram submissos aos seus senhores, eram obrigados a participar das cerimônias do costume europeu, dirigidas pela igreja católica. Os negros sempre faziam seus rituais com cantos e danças para seus orixás e vale ressaltar que as festas religiosas são referências entre diferentes culturas que povoaram o Brasil dando assim a origem à cultura nacional. Os negros eram associados a irmandades por diferentes etnias, conservando sua própria cultura, com união e soluções de problemas.

A música de Beiradão está presente nas festas que são feitas em pequenos municípios ou comunidades ribeirinhas de margem para o rio, locais que só podem chegar através de transporte fluvial. As sedes eram locais onde aconteciam os bailes e folga depois das procissões e eram feitas de palafita com assoalho. Com isso, os músicos se integraram nas comunidades, pois, tinham necessidade de acompanhamento dos hinos.

Nos anos 20 ouve algumas inovações, as comunidades passaram a ter o contato com novas formas de tecnologia de comunicação em longa distância como rádio. Isso levou as populações dos interiores ao contato com outros estilos musicais e gradativamente as músicas tocadas nas festas foram se modificando, essa foi uma forma de colaborar musicalmente nas festas e cantos da igreja.

Nos anos 70 o desenvolvimento tecnológico representado pelas energias elétricas e caixa de som, está associado a ampliação da instrumentação (guitarra e órgão) e de repertórios, tais como o samba, brega, forró.

Apresentamos brevemente a trajetória de quatro músicos amazonenses desta geração. Chico Cajú nasceu no interior do Amazonas, no Lago do Ajará, nasceu em uma família de músicos, sua carreira como saxofonista iniciou nas sedes e beiradas nos municípios do interior do Amazonas, aos 20 anos ganhou de seu pai um saxofone alto, nisto era convidado para vários festejos e apresentações. Cajú participou da Banda Pop com formação de vários instrumentos, e também o vocal.

Teixeira de Manaus nasceu na Costa do Catalão, uma comunidade no interior do município de Iranduba, e foi influenciado pelo pai que também era músico. Aprendeu sozinho o saxofone, com o qual

${ }^{3}$ (NORBERTO, 2016); (LIMA, 2020); (TEIXEIRA, 2018). 
fazia várias apresentações em festas de aniversário. Nos anos 70 montou seu próprio grupo musical RT4, desde aí ficou conhecido, e chamado de Maestro Teixeira. Teixeira teve sucesso na sua gravação e foi prestigiado nos anos 80 por ser um dos precursores do estilo de música instrumental.

Roberto Bope nasceu na Ilha das Cobras, interior de Parintins, teve a oportunidade de conhecer a música quando criança e aos 19 anos iniciou a carreira musical. Foi um dos criadores e participante do grupo Canoeiro e também criou a Banda Carrapicho, tocava em diversos eventos como casamentos e prostíbulos, mesmo sem o apoio dos seus pais seguiu firme na carreira de músico e foi um dos nomes do nativismo musical na Amazônia.

Ozeas Silva é natural da comunidade do São Raimundo, seu pai presenteou com seus primeiros instrumentos musicais, participou do conjunto Uirapuru como guitarrista no decorrer do tempo foi se desenvolvendo na música e tocando em vários locais da cidade, e se destacando com um dos primeiros nomes da guitarra na Amazônia. Ao sucesso do primeiro compacto, fez seu álbum solo na gravadora de São Paulo, Ozeas tinha um estilo único com a guitarra sempre impressionando ao público com solos elaborados.

A condição de migrantes destes músicos permite pensarmos sua música como um processo em movimento dialético dentro da expansão capitalista da região. Embora na infância seu aprendizado musical tenha ocorrido dentro de um contexto rural, através das formas de transmissão oral no seio de suas famílias e comunidades, não podemos congelar neste período, o dinâmico processo de aprendizagem destes músicos no curso da transformação de suas vidas sociais.

\section{Referências}

ALMEIDA, Mauro W. B. Marxismo e Antropologia. Em Armando Boito Jr. e Caio N. de Toledo (orgs.) Marxismo e Ciências humanas. São Paulo: Xamã/FAPESP/CEMARX, 2003, pp. 75-85.

ÁLVARES, Lucas Parreira. Para uma crítica da razão antropológica. 2019. Práxis Comunal, Belo Horizonte: v.2, n.1 2019 | ISSN: 2596-1020.

BENCHIMOL, Samuel. Amazônia: Formação social e cultura. Manaus: Valer, 1999.

BOSCHI, Caio César. Os Leigos e o Poder (Irmandades Leigas e Política colonizadora em MG). São Paulo: Editora Ática, 1986.

CARDOSO, Fernando Henrique; MÜLLER, Geraldo. Amazônia: Expansão do capitalismo. São Paulo: Brasiliense, 1977.

CARVALHO, Edgar de A. Marxismo, Etnia e Reprodução social. Revista de ciências sociais da Unesp, perspectiva, São Paulo, 1988.

COSTA, Maria J. J. Demografia e Mão-de-obra na Amazônia. Belém: Centro de Filosofia e Ciência Humanas/NAEA/UFPA, 1990.

FERREIRA, Talita S. M. C.; GOMES Jocilene Gomes. Festa de Nossa Senhora do Carmo de Parintins/AM: Celebração da fé e Turismo Cultural. Universidade do Estado do Amazonas - UEA.

GALVÃO, Eduardo. Santos e Visagens: um estudo da vida religiosa de Itá, baixo Amazonas. $2^{\circ}$ ed, São Paulo. Brasília, INL, 1976. 
HARRIS, Marvin. El desarrollo de la teoria antropologica: história de las teorias de la cultura. Ciudad de Mexico: Siglo Veintiuno, 1979. 690 p.

IANNI, Octavi. Ditadura e agricultura: o desenvolvimento do capitalismo na Amazônia. - Rio de janeiro: Civilização 1986.

LIMA, Rafael Angelo dos Santos. Os "motivos" das guitarras amazonenses: diálogos culturais e invenções entre fronteiras. Dissertação apresentada ao programa de pós-graduação sociedade e cultura na Amazônia da Universidade Federal do Amazonas como exigência parcial para a obtenção de título de mestre, Ufam, 2020.

LOUREIRO, João J. P; JESUS, João de. Cultura Amazônica: uma poética do imaginário. $5^{\mathrm{a}}$ edição. Manaus: Valer Editora, 2015.

LOUREIRO, Violeta Refkalefsky. A Miséria da Ascensão Social: Capitalismo e Pequena Produção na Amazônia. Ed. Marco Zero, 1987.

LUCKÁS, György. Prolegômenos para uma ontologia do ser social. Traduzido por Sergio Lessa e revisado por Mariana Andrade. Maceió: Coletivo Veredas, 2018.

MARCUS, Gyorgy. Marxismo y Antropologia. Edicion: Francisco Fernandéz Buey. Tradução Manuel Sacristán, 1974.

MARX, KARL. O Capital: crítica da Economia Política. Livro I: o processo de produção do capital/ Karl Marx; tradução Rubens Enderle. 2ed. São Paulo: Boitempo, 2017.

MELLO, Mario Lacerda de; MOURA, Hélio A. de. Migrações para Manaus, prefácio de Clóvis Cavalcanti. Recife: FUNDAJ, Editora Massangana, 1990.

NORBERTO, Rafael B.A. Espaços, trânsitos e sociabilidades em performance na música do Beiradão: uma etnografia entre músicos amazonenses. 155p. Dissertação Mestrado Universidade Federal do Rio Grande do Sul, Instituto de Artes, Programa de pós-graduação em música, Porto Alegre. 2016.

SILVA, Jamily Souza da. A festa de São Benedito no bairro da Praça 14 de Janeiro. Culturas populares em meio urbano. Manaus: EDUA, 2012.

TEIXEIRA, Darle Silva. O Beiradão está em festa: A obra musical de Teixeira de Manaus nos anos 80 e sua influência junto às festas do Beiradão. Manaus: UEA, 2018.

TERRAY, Emmanuel. O Marxismo diante das sociedades primitivas: dois estudos. Tradução de Manoel Barros da Motta e Venusia Cardoso Neiva. Rio de Janeiro: Edições Graal, 1979.

TINHORÃO, José Ramos. As festas no Brasil colonial, $1^{\text {a }}$ ed. São Paulo Ed.34, 2000. Festa de negro em devoção de branco: do carnaval na procissão ao teatro no círio. São Paulo: Editora Unesp, 2012.

WAGLEY, Charles. Uma Comunidade Amazônica. Estudo do Home nos Trópicos, 1957.

Recebido em 30/10/2020

Aceito em 23/11/2020 